\title{
ERRATUM
}

Med \& Health 2021 Jun 16(1): 190-206. doi: 10.17576/MH.2021.1601.16

\section{Knowledge and Perception of Malaysian Forest Fringe Population towards Zika Infection}

\author{
ROZITA $\mathrm{H}^{1}$, CHIN MUN W ${ }^{1 *}$, MOHD ROHAIZAT H ${ }^{1}$, NADIA \\ AQILLA S ${ }^{2}$, HANI KARTINI ${ }^{2}$, RAJA MOHD AZIM RH ${ }^{3}$, \\ SHARIFAH EZAT WP ${ }^{1}$, SAZALY AB ${ }^{4}$
}

\begin{abstract}
'Department of Community Health, Faculty of Medicine, Universiti Kebangsaan Malaysia Medical Centre, Jalan Yaacob Latif, Bandar Tun Razak, 56000 Cheras, Kuala Lumpur, Malaysia

${ }^{2}$ Department of Earth Sciences \& Environment, Faculty of Science and Technology, Universiti Kebangsaan Malaysia, 43600 Bangi, Selangor, Malaysia

${ }^{3}$ Public Health Physician, District Health Office Batang Padang Perak, Jalan Temoh, 35000 Tapah, Perak Darul Ridzuan, Malaysia

${ }^{4}$ Department of Tropical Infectious Diseases Research \& Education Center (TIDREC) University Malaya, Jalan Universiti, Lembah Pantai, 50603 Kuala Lumpur, Malaysia
\end{abstract}

According to the request by the author, the acknowledgement section is added to the manuscript:

\section{ACKNOWLEDGEMENT}

The authors would like to thank the Ministry of Higher Education Malaysia under Long Term Research Grant Scheme (LRGS) MRUN/F1/01/2018 for funding this project. 